that smoking habit might determine which of the two diseases develops. They also observed that cigarette smoking is associated with increased consumption of refined sugar and that such consumption has consistently been associated with Crohn's disease. Studies of diet have not, however, shown any association between consumption of refined sugar and ulcerative colitis. Furthermore, Thornton et al recently provided evidence that smoking and a high consumption of refined sugar show independent positive associations with the development of Crohn's disease."

With regard to use of oral contraceptives our data on Crohn's disease, indicating a possible increased risk of the disease in those taking the pill, are consistent with the findings of others. ${ }^{\times 1011}$ In our study the use of oral contraceptives was, however, more strongly associated with ulcerative colitis than with Crohn's disease, though even this association fell just short of conventional levels of significance in the adjusted analysis (see table III). The only other studies of the relation between the use of oral contraceptives and ulcerative colitis have been performed by the Royal College of General Practitioners, which found a positive association, ${ }^{\star}$ and by Rhodes et al, who did not."

It might be argued that women developing such a disabling condition as chronic inflammatory bowel disease would want to avoid pregnancy at all costs and might, therefore, switch to oral contraception, thus producing a spurious positive association between the pill and disease. This argument does not, however, explain our observations. Firstly, as far as was possible, we identified the date of onset of disease in each woman and related use of contraceptives to that date. Secondly, the association between use of the pill and disease was stronger in those who had been using oral contraceptives for a long time than in those who had recently started this method of birth control.

If oral contraceptives do have an aetiological role in chronic inflammatory bowel disease (and this cannot yet be regarded as established) the mechanism of their action is obscure. The suggestion, however, that colonic Crohn's disease is particularly associated with use of the pill points towards a possible vascular basis for the lesion, as there have been several cases of acute segmental colitis associated with the oral contraceptive pill that have been interpreted as having an ischaemic aetiology. ${ }^{1 \times 19}$

We thank Mrs P Brown, Mrs D Collinge, Miss C Henry, our research assistants, and all the doctors, nurses, and administrative staff working in the participating clinics. We are also grateful to the pathologists and their technicians for help in providing extra data and to the Medical Research Council for financial support.

\section{References}

I Harries AD, Baird A, Rhodes J. Non-smoking: a feature of ulcerative colitis. Br Med $\mathrm{f}$ 1982;284:706

2 Bures J, Fixa B, Komarkova O, Fingerland A. Non-smoking: a feature of ulcerative colitis. $\mathrm{Br}$ Med F 1982;285:440.

3 Jick H. Walker AM. Cigarette smoking and ulcerative colitis. N Engl f. Med 1983;308:261-3.

+ Benoni C. Nilsson A. Smoking habits in patients with inflammatory bowel disease. Scand f (jastroenterol 1984:19:824-30.

Logan RFA, Edmond M, Somerville KW', Langman MJS. Smoking and ulcerative colitis. Br.Med $\mathcal{f} 1984 ; 288: 751-3$

6 Thornton JR. Emmett PM. Heaton KW. Smoking, sugar, and inflammatory bowel disease. $\mathrm{Br}$ Med F 1985;290:751-2.

Somerville KW, Logan RFA, Edmond M, Langman MJS. Smoking and Crohn's disease. Br.Med 7 1984:289:954-6.

8 Royal College of General Practitioners. Oral contraceptives and health. London: Pitman Medical. 1974 .

9 Bonfils S, Hervoir P, Girodet J, Le Quintrec Y, Bader JP, Gastard J. Acute spontaneously recovering ulcerating colitis (ARUC). Dig Dis Sit 1977;22:429-36.

10 Rhodes JM. Cockel R, Allan RN, Hawker PC. Dawson J. Elias E. Colonic Crohn's disease and use of oral contraception. Br.Med f 1984;288:595-6.

11 Lesko S, Kaufman D, Rosenberg L, Helmrich S, Miller D, Shapiro S. Oral contraceptive use and Crohn's disease. Am 7 Epidemiol 1984;120:466.

12 Vessev M, Doll R, Peto R, Johnson B, Wiggins P. A long term follow up study of women using different methods of contraception-an interim report. 7 Biosoc $S_{C 1} 1976 ; 8: 373-427$.

13 Evans JG, Acheson ED. An epidemiological studv of ulcerative colitis and regional enteritis in the Oxford area Gut 1965:6:311-24.

14 Kyle J. An epidemiological study of Crohn's disease in northeast Scotland. Gastroenterologv 1971; $61: 826-33$

15 Devlin HB. Datta D, Dellipiani AW. The incidence and prevalence of inflammatory bowel disease in North Tees health district. W'orld 7 S Surg 1980;4:183-93.

16 Mayberry JF, Rhodes J. Epidemiological aspects of Crohn's disease: a review of the literature. ( iut 1984:25:886-99.

17 Lee FI, Costello FT. Crohn's disease in Blackpool-incidence and prevalence 1968-80. (iul $1985 ; 26: 274-8$

18 Cotton PB, Lea Thomas M. Ischaemic colitis and the contraceptive pill. Br Med 7 1971;iii:27-8.

19 Kilpatrick ZM, Silverman JF, Betancourt E, Farman J, Lawson JP. Vascular occlusion of the colon and oral contraceptives. N Engl f. Hed 1968;278:438-40.

Accepled H March 1986

\title{
Increase in bronchopulmonary infection due to Branhamella catarrhalis
}

\author{
D T MCLEOD, F AHMAD, S CAPEWELL, M J CROUGHAN, MARGARET A CALDER, \\ A SEATON
}

\begin{abstract}
In a six month prospective study during the winter Branhamella catarrhalis was isolated from the sputum of 63 patients with symptoms of bronchopulmonary infection: 49 isolates were in pure culture and 14 were with another pathogen, Haemophilus influenzae being the commonest (found with 10 of the 14 B catarrhalis isolates). Of 36 patients infected in the community, 26 required admission to hospital. The remaining 27 patients
\end{abstract}

\footnotetext{
Chest Unit and Department of Bacteriology, City Hospital, Edinburgh E10 5SB

D T MCLEOD, MRCP, medical registrar, chest unit

F AHMAD, MB, MIBIOL, registrar in bacteriology

S CAPEWELL, MRCP, medical registrar, chest unit

M J CROUGHAN, FIMLS, senior chief medical laboratory scientific officer

MARGARET A CALDER, MD, consultant bacteriologist

A SEATON, MD, FRCP, consultant physician, chest unit

Correspondence to: Dr D T McLeod, North Tees General Hospital, Stockton on Tees, Cleveland TS19 8PE.
}

were infected while in hospital. Forty four of the 63 isolates produced $\beta$ lactamase; 26 of these had been acquired in the community. As a result 29 patients were treated inappropriately with ampicillin and did not respond to this treatment. $\beta$ Lactamase produced by $B$ catarrhalis may also protect other pathogens normally susceptible to $\beta$ lactam antibiotics. Most patients had chronic lung diseases or lung cancer, but three otherwise healthy patients who did not smoke developed bronchitis. B catarrhalis contributed to the death of five patients.

A survey of the antibiotic prescribing habits of the referring general practitioners together with the sensitivity results of B catarrhalis suggest that changes in antibiotic prescribing habits in the community may be responsible for the increase in $B$ catarrhalis infection.

\section{Introduction}

Branhamella catarrhalis, previously considered to be a harmless oropharyngeal commensal, is being recognised increasingly as an important pathogen. Its presence in the oropharynx lends itself to 
endogenous spread, most commonly to the middle ear causing otitis media $^{1}$ or by aspiration causing bronchopulmonary disease. ${ }^{23}$ Patients with such infections have previously responded to treatment with ampicillin, but the organism's capacity to produce $\beta$ lactamase, first noted in $1977,{ }^{4}$ has conferred penicillin resistance, thus complicating what was a simple choice of antibiotic. In less than a decade the proportion of strains producing $\beta$ lactamase has risen to over a half.

In Edinburgh significant growth of $B$ catarrhalis from purulent sputum is always reported; a noticeable increase in the rate of isolation from patients suffering from bronchopulmonary infection admitted to the medical wards has thus been noted. ${ }^{5}$ The reason for this increase is obscure. To study possible factors contributing to this increase in the rate of isolation and also the increase in the proportion of strains producing $\beta$ lactamase a prospective six month study was conducted from November 1983 to April 1984.

\section{Methods}

All sputum samples from hospital wards, outpatient departments, and local general practices received by the bacteriology laboratory at the City Hospital, Edinburgh, during November 1983 to April 1984 were studied. Our method of bacteriological screening of sputum has not altered for several years. ${ }^{5}$ Sensitivity tests to penicillin, ampicillin, chloramphenicol, erythromycin, co-trimoxazole, trimethoprim, Augmentin (clavulanate potentiated amoxycillin), cefotaxime, and cefuroxime were performed by the disc diffusion method. Clinical details, findings of chest radiography, and virological titres were reviewed in all patients whose sputum yielded a pure culture of $B$ catarrhalis or a mixed culture with other respiratory pathogens in which $B$ catarrhalis was the predominant organism. Previous antibiotic treatment and the initial antibiotic chosen on admission to hospital were recorded. A simple questionnaire sent to all general practitioners who had referred patients in whom $B$ catarrhalis had been isolated from sputum samples requested details of their preference for antibiotics in the treatment of chest infections among ampicillin, amoxycillin, co-trimoxazole, erythromycin, a cephalosporin, tetracycline, and "other."

\section{Results}

During the six months of the study $B$ catarrhalis was isolated from the sputum of 48 men and 15 women (mean age 69 years, range 21-88) (table). $B$ catarrhalis was isolated in pure culture from the sputum of 49 patients. The examined during the corresponding six months from November to April in the previous five years was constant at roughly 3000 specimens.

Chronic pulmonary diseases in the 63 patients included chronic bronchitis and emphysema (in 33 patients), carcinoma bronchus (13), asthma (eight), congestive cardiac failure (five), pulmonary fibrosis or bronchiectasis (four), and polymyalgia rheumatica (one). Pneumonia occurred in three patients. Respiratory syncytial virus may have predisposed one otherwise healthy non-smoking octogenarian to infection. Two previously healthy non-smoking junior hospital doctors developed tracheobronchitis with $\beta$ lactamase negative strains of $B$ catarrhalis, one after infection with Mycoplasma pneumoniae and the other after a coryzal illness. The 63 patients comprised 40 smokers, 12 ex-smokers (who had not smoked for at least one year), six non-smokers, and five patients whose smoking state was unknown.

Of 36 patients infected in the community, 26 had $B$ catarrhalis in their sputum on admission to hospital, seven were attending hospital outpatient departments, and three were attending general practices. Among these 36 patients, 26 had strains of $B$ catarrhalis that produced $\beta$ lactamase and 10 had been treated unsuccessfully with ampicillin. None had received treatment with trimethoprim

Twenty seven patients became infected with $B$ catarrhalis in hospital; in 18 $\beta$ lactamase production was present. Overall, 44 out of the 63 strains produced $\beta$ lactamase.

All the isolates were sensitive to Augmentin, erythromycin, chloramphenicol, co-trimoxazole, cefotaxime, and cefuroxime, but all were resistant to trimethoprim. The $19 \beta$ lactamase negative strains were uniformly sensitive to penicillin and ampicillin.

Forty seven of the $49 \mathrm{GPs}$, in 31 practices, responded to the questionnaire. Thirty seven GPs stated ampicillin or amoxycillin as their antibiotic of first choice, five tetracycline, three erythromycin, three cephradine, and one cotrimoxazole.

The hospital doctors' first choice of antibiotic for patients subsequently found to have bronchopulmonary infection due to $B$ catarrhalis included ampicillin (20 doctors), Augmentin (for patients who had not responded to ampicillin before admission) (eight), erythromycin (one), chloramphenicol (one), and flucloxacillin (one). Overall, 26 patients had received ampicillin inappropriately in the presence of $\beta$ lactamase producing strains of $B$ catarrhalis. When the results of antibiotic sensitivity tests were available the alternatives to ampicillin treatment chosen by the hospital doctors were Augmentin (14 doctors), co-trimoxazole (six), erythromycin (two), chloramphenicol (one), and cephradine (one).

$B$ catarrhalis contributed to the deaths of five patients: three had carcinoma bronchus, one chronic bronchitis, and one cerebrovascular accident. Five patients with mild symptoms recovered without antibiotic treatment. The hospital stay of two patients was prolonged because of recurrent infection with $\beta$ lactamase producing $B$ catarrhalis as a result of doctors initially ignoring the bacteriological report and continuing treatment with ampicillin. They all responded promptly to Augmentin treatment.

Number of isolates of B catarrhalis causing bronchopulmonary infection from fanuary 1981 to April 1984

\begin{tabular}{|c|c|c|c|c|c|c|c|c|}
\hline & \multicolumn{2}{|c|}{1981} & \multicolumn{2}{|c|}{1982} & \multicolumn{2}{|c|}{1983} & \multicolumn{2}{|c|}{1984} \\
\hline & $\begin{array}{l}\text { Total } \\
\text { No of } \\
\text { isolates }\end{array}$ & $\begin{array}{c}\text { No of } \\
\text { isolates } \\
\text { producing } \\
\beta \text { lactamase }\end{array}$ & $\begin{array}{l}\text { Total } \\
\text { No of } \\
\text { isolates }\end{array}$ & $\begin{array}{c}\text { No of } \\
\text { isolates } \\
\text { producing } \\
\beta \text { B lactamase }\end{array}$ & $\begin{array}{l}\text { Total } \\
\text { No of } \\
\text { isolates }\end{array}$ & $\begin{array}{c}\text { No of } \\
\text { isolates } \\
\text { producing } \\
\beta \text { lactamase }\end{array}$ & $\begin{array}{l}\text { Total } \\
\text { No of } \\
\text { isolates }\end{array}$ & $\begin{array}{c}\text { No of } \\
\text { isolates } \\
\text { producing } \\
\text { prlactamase }\end{array}$ \\
\hline January & 1 & 1 & 13 & 6 & 22 & 14 & 14 & 9 \\
\hline February & 5 & 2 & 9 & 3 & 14 & 5 & 5 & 4 \\
\hline March & 4 & 2 & 5 & 2 & 15 & 7 & 14 & 12 \\
\hline April & 2 & i & 1 & 0 & 4 & 4 & 11 & 9 \\
\hline May & 0 & 0 & 0 & 0 & 14 & 11 & & \\
\hline June & 1 & 0 & 3 & 2 & 11 & 9 & & \\
\hline July & 2 & 0 & 3 & 1 & 8 & 4 & & \\
\hline August & 4 & 3 & 2 & 0 & 2 & 1 & & \\
\hline September & 3 & 1 & 1 & 0 & 4 & 2 & & \\
\hline October & 2 & 1 & 1 & 0 & 3 & 1 & & \\
\hline November & 4 & 2 & 8 & 3 & 14 & 8 & & \\
\hline December & 4 & 1 & 18 & 11 & 5 & 2 & & \\
\hline
\end{tabular}

Gram stain of these sputum samples showed numerous neutrophils with many intracellular and extracellular Gram negative diplococci. In the remaining 14 patients $B$ catarrhalis was isolated with one other pathogen: $\beta$ lactamase producing strains of $B$ catarrhalis were present with eight of the 10 strains of Haemophilus influenzae isolated, one of the two strains of Staphylococcus aureus, and one strain of Streptococcus pneumoniae. A $\beta$ lactamase negative strain of $B$ catarrhalis was isolated with one strain of Pseudomonas aeruginosa. The strains of $B$ catarrhalis producing $\beta$ lactamase may have protected the strains of $H$ influenzae, all of which were $\beta$ lactamase negative, from ampicillin. The total number of routine sputum samples

\section{Discussion}

$H$ influenzae and Strep pneumoniae are responsible for most infective exacerbations of chronic bronchitis. During the past two years, however, $B$ catarrhalis has become an important pathogen in the winter months as over $70 \%$ of strains produce $\beta$ lactamase and thus do not respond to treatment with ampicillin, the standard drug of first choice. Moreover, as $B$ catarrhalis is not a fastidious organism (it can survive in dried sputum for 27 days $^{6}$ ) nosocomial spread may 
result $^{7}$; almost half of our patients acquired their infection in hospital.

Previous reports accept that $B$ catarrhalis infection occurs in immune compromised hosts ${ }^{89}$ or in patients with chronic pulmonary disorders, ${ }^{2.3}$ but our finding of infection in otherwise healthy non-smoking adults, supported by others, ${ }^{3}$ suggests that there may be an increase in the number of more virulent strains. Historically, the virulence of $B$ catarrhalis seems to have fluctuated. In the early part of this century it was associated with epidemics of severe "flu like" illness. ${ }^{10}$ Thereafter its appearance in reports, usually in cases of meningitis, endocarditis, or conjunctivitis, was sporadic until the mid-1970s. Since then the number of reports from different countries suggests that more virulent organisms are appearing rather than simply reflecting an increased tendency to report them.

The pathogenic mechanisms of $B$ catarrhalis are still poorly understood. Its deoxyribonuclease production enables it to inflame mucous membranes. Unlike Neisseria gonorrhoeae and Neisseria meningitidis, $B$ catarrhalis does not produce IgAl proteases, which cleave $\mathrm{IgAl}$ into $\mathrm{Fab}$ and $\mathrm{Fc}$ portions and thus breach the protective immunoglobulin barrier of the mucous membrane."

Other members of the family Neisseriaceae have not been studied as extensively as $N$ gonorrhoea and $N$ meningitidis as generally they have been regarded as harmless organisms of little clinical import. As $B$ catarrhalis has recently been causing disease more often than is normally expected microbiologists and clinicians should not dismiss it too readily as normal flora.

The reason for this resurgence is obscure, though the role of antibiotic pressure warrants careful scrutiny. Ampicillin has been used widely in the Edinburgh area, and this may have played a part in increasing the number of strains of $B$ catarrhalis producing $\beta$ lactamase. Similarly, trimethoprim, though not used as extensively in Edinburgh, has been shown to induce bacterial resistance to itself. $^{12}$ The increasing use of such antibiotics may alter the nasopharyngeal flora sufficiently to lead to an increased incidence of infections with $B$ catarrhalis. Further studies are required to test this hypothesis.

We thank Professor D C Flenley and our respiratory consultant colleagues at the City Hospital, Edinburgh, for permission to study their patients, the staff of the bacteriology department for technical help, and Linda Heslop for secretarial help.

\section{References}

1 Kamme $\mathrm{C}$, Lundgren $\mathrm{K}$, Mardh $\mathrm{P}$. The aetiology of acute otitis media in children. Scand $\mathcal{I}$ Infect Dis 1971:3:217-23.

2 Ninane G, Joly J, Kraytman M. Bronchopulmonary infection due to Branhamella catarrhalis: 11 cases assessed by transtracheal puncture. $\operatorname{Br}$ Med $\mathcal{7}$ 1978;i:276-8.

Slevin NJ, Aitken J, Thornley PE. Clinical and microbiological features of Branhamella catarrhalis bronchopulmonary infection. Lancet $1984 ;$; $: 782-3$.

4 Malmvall BE, Brorsson JE, Johnsson J. In vitro sensitivity to penicillin $V$ and beta-lactamase production of Branhamella catarrhalis. F Antimicrob Chemother 1977;3:374-5.

production of Branhamella catarrhalis. F Antmicrob Chemother 1977:3:374-5.
McLeod DT, Ahmad F, Power JT, Calder MA, Seaton A. Bronchopulmonary infection due to Branhamella a a

Wilson GS, Miles AA. Neisseria. In: Topley WRC, Wilson GS, eds. Principles of bacteriology and immunty. I.ondon: Edward Arnold, 1964:665-92.

Ahmad F, McLeod DT, Power JT, Calder MA. Branhamella catarrhalis prevalence in a hospital population. F Hosp Infect 1985;6:71-4.

8 McNeely DJ, Kitchens CS, Kluge RM. Fatal Neisseria Branhamella catarrhalis pncumonia in an immunodeficient host. Am Rev Respir Dis 1976;114:399-402.

9 Diamond LA, Lorber B. Branhamella catarrhalis pneumonia and immunoglobulin abnormalities: a new association. Am Rev Respir Dis 1984;129:876-7

10 Dunn RA, Gordon MH. Remarks on the clinical and bacteriological aspects of an epidemic simulating influenza. Br.Med 7 1905;ii:421-7.

11 Mulks MH, Plaut AG. IgA protease production as a characteristic distinguishing pathogenic from harmless Neisseriaceae. N Engl f Med 1978;299:973-6.

12 Lacey RW, Lord VL, Gunasekera HKW', Leiberman PJ, Luxton DEA. Comparison of trimethoprim alone with trimethoprim sulphamethoxazole in the treatment of respiratory and trimethoprim a $1980 ;$ i: $1270-3$.

Accepted 28 Februan 1986

\section{SHORT REPORTS}

\section{Metabolic acidosis due to D-lactate}

Metabolic acidosis caused by $\mathrm{D}(-)$-lactic acid has been well documented in patients after bowel surgery.' I describe a patient who had not undergone bowel surgery but developed $\mathrm{D}(-)$-lactic acidosis; this has not been reported before.

\section{Case report}

A 60 year old man had a 10 year history of chronic pancreatitis; he had undergone cholecystectomy nine years previously and a Peustow procedure (filleting of the pancreatic duct and jejunal anastomosis) seven years previously He had also been treated with pancreatic enzymes and cimetidine. He developed chronic renal failure (interstitial nephritis), and haemodialysis was started when he was 59; shortly afterwards he received a cadaveric renal allograft. Immunosuppression with azathioprine and prednisolone was started. The early course after transplantation was complicated by four episodes of rejection, each treated with methylprednisolone, and by the development of diabetes mellitus, which was treated with insulin.

Two months after transplantation he had been well with stable but poor graft function until he was readmitted after a week of lethargy and nausea and vomiting. On examination he did not have a fever but was poorly perfused, cyanosed, tachypnoeic ( 48 breaths/min) and hypotensive. His haemoglobin concentration was $125 \mathrm{~g} / \mathrm{l}$, white cell count $3.4 \times 10^{9} / 1$, sodium concentration $141 \mathrm{mmol}(\mathrm{mEq}) / \mathrm{l}$, potassium $4.4 \mathrm{mmol}(\mathrm{mEq}) / 1$, chloride $103 \mathrm{mmol}(\mathrm{mEq}) / \mathrm{l}$, bicarbonate $13 \mathrm{mmol}(\mathrm{mEq}) / 1$, urea $21 \mathrm{mmol} / 1(126 \mathrm{mg} / 100 \mathrm{ml})$, and creatinine $193 \mu \mathrm{mol} / \mathrm{l}(2 \cdot 2 \mathrm{mg} / 100 \mathrm{ml})$. He also had acidosis with $\mathrm{pH} 7 \cdot 3$, oxygen tension $11.4 \mathrm{kPa}(86 \mathrm{~mm} \mathrm{Hg})$, carbon dioxide tension $2.7 \mathrm{kPa}(20 \mathrm{~mm} \mathrm{Hg})$, standard bicarbonate $14 \mathrm{mmol}(\mathrm{mEq}) / \mathrm{l}$, and base excess $-16 \mathrm{mmol}(\mathrm{mEq}) / \mathrm{l}$; the anion gap was $29 \mathrm{mmol}(\mathrm{mEq}) / 1$, and $\mathrm{L}(+)$-lactate concentration was low at $1.1 \mathrm{mmol} / \mathrm{l}$ $(9.9 \mathrm{mg} / 100 \mathrm{ml})$. There was no evidence of salicylates, $\beta$-hydroxybutyrate, or ketones in the blood, and the glucose concentration was $6.8 \mathrm{mmol} / \mathrm{l}(123 \mathrm{mg}$ $100 \mathrm{ml})$. The $\mathrm{D}(-)$-lactate concentration was $6.8 \mathrm{mmol} / \mathrm{l}(61 \mathrm{mg} / 100 \mathrm{ml})($ normal $<0 \cdot 2 \mathrm{mmol} / 1(<1.8 \mathrm{mg} / 100 \mathrm{ml}))$

He was treated for suspected sepsis (subsequent blood cultures grew Escherichia coli) with broad spectrum antibiotics (ampicillin, flucloxacillin, and gentamicin) and was given sodium bicarbonate. After a respiratory arrest requiring ventilation he was given haemodialysis with bicarbonate dialysate. He deteriorated, became anuric and hypotensive, and developed progressive lung shadowing; he died two days later.

Method of measuring $D(-)$-lactate-The $\mathrm{D}(-)$-lactate concentration was measured by substituting $\mathrm{D}(-)$-lactate dehydrogenase (EC 1.1.1.28, Boehringer Mannheim Biochemicals, No 106941) for $L(+)$-lactate dehydrogenase (EC 1.1.1.27) in the kit for estimating lactate (Boehringer Mannheim Biochemicals test combination No 139084).

\section{Comment}

$\mathrm{D}(-)$-lactic acidosis has been well described in association with the short bowel syndrome after jejunoileal bypass surgery, most commonly for obesity. ${ }^{1-5}$ The syndrome has not been reported in patients who have not had bowel surgery. High concentrations of $D(-)$-lactate have been associated with dizziness, ataxia, dysarthria, fatigue, confusion, headache, and other neurological syndromes. ${ }^{134}$ The $\mathrm{D}(-)$-lactate has been assumed to result from the metabolism of carbohydrate by bacteria abnormally found in the small bowel, or after the rapid transit of carbohydrate to the large bowel. If the amount of $\mathrm{D}(-)$-lactate produced exceeds the capacity for further metabolism then it will be absorbed.

The acidosis in this patient was thought to be disproportionate to the degree of renal impairment. Blood was therefore screened for other possible acids, including $\mathrm{D}(-)$-lactic acid, which is a cause of acidosis. ${ }^{1} \mathrm{D}(-)$-Lactate is normally undetectable, ${ }^{4}$ and the measured concentration of $6.8 \mathrm{mmol} / \mathrm{l}$ $(61 \mathrm{mg} / 100 \mathrm{ml})$ suggests that this contributed greatly to the acidosis. Unfortunately the organism cultured from his blood was not characterised for its ability to produce $\mathrm{D}(-)$-lactate. $E$ coli is not known to produce $\mathrm{D}(-)$-lactate, and the source may have been another gut organism. This patient had not undergone surgery resulting in anatomical or functional bowel shortening, and, although the Peustow procedure may sometimes be associated with creation of a blind loop, he did not have a history of diarrhoea or other suggestive features. The source of the $D(-)$-lactate is therefore speculative. 